\title{
SÉRIE "Ekonomika”
}

https://doi.org/10.52058/2695-1592 -2021-2(2)-93-106

\section{Тамара Панфілова}

кандидат економічних наук, старший науковий співробітник, провідний науковий співробітник сектору міжнародних фінансових досліджень Державної установи «Інститут економіки та прогнозування НАН Украӥни», м. Київ, Україна,e-mail: tamara.panfilova@gmail.com, https://orcid.org/0000-0002-1410-6258

\section{ЕФЕКТИ ПРОЦЕСІВ КОНВЕРГЕНЦІЇ ТА ДИВЕРГЕНЦІї У ТОРГОВЕЛЬНІЙ ПОЛІТИЦ ЄВРОПЕЙСЬКОГО СОЮЗУ}

Анотація. У статті наведено результати дослідження щодо процесів конвергенції та дивергенції у торговельних відносинах країн-членів Свропейського Союзу внаслідок реалізації політики розширення. Розкрито сутність трансформації спільної торговельної політики ЄС на національному, наднаціональному та міжнародному рівнях. Окреслено місце України в торгівлі товарами в рамках «Східного партнерства» та застереження щодо порушень прав інтелектуальної власності в торговельних відносинах.

Оцінено ефективність торговельної політики $\mathrm{CC}$, яка визначається динамікою експорту та імпорту товарів і послуг як на зовнішніх ринках, так i на Спільному ринку інтеграційного угруповання. Проведений статистичний аналіз дозволив визначити: (i) лідерські позиції $Є \mathrm{C}$ на зовнішніх ринках (друге місце в торгівлі товарами та перше місце в торгівлі послугами) за умови позитивної динаміки експорту та імпорту товарів і послуг в 2010-2019 pp.; (ii) переважання завдяки процесам торговельної конвергенції в національному експорті та імпорті товарів питомої ваги торговельних відносин 3 країнамичленами співтовариства (понад 50\%); (iii) основні прояви торговельної дивергенції постають у домінуванні 5 країн в експортно-імпортних відносинах на внутрішньому ринку, значній диференціації за темпами приросту експорту та імпорту товарів у торгівлі на внутрішньому ринку тощо.

Отримані результати дозволяють констатувати значний ефект конвергенції країн-членів СС завдяки трансформації торговельної політики спільноти і розбудові Спільного ринку практично для усіх країн ЄС-27.

Ключові слова: Європейський Союз, торговельна політика, конвергенція, дивергенція, Спільний ринок, експорт та імпорт товарів. 


\title{
Tamara Panfilova
}

PhD (Econ.) (Ukraine), Senior Research Fellow, Leading Researcher of the Sector of International Finance Research of the Institute for Economics and Forecasting of the NAS of Ukraine, Kyiv, Ukraine, e-mail: tamara.panfilova@gmail.com,https://orcid.org/0000-0002-1410-6258.

\section{EFFECTS OF CONVERGENCE AND DIVERGENCE PROCESSES IN THE TRADE POLICY OF THE EUROPEAN UNION}

\begin{abstract}
The article presents the results of a study on the processes of convergence and divergence in trade relations of European Union member states as a result of the implementation of enlargement policy. The essence of the transformation of the common trade policy of the EU at the national, supranational and international levels is revealed. Ukraine's place in trade in goods within the framework of the Eastern Partnership and warnings about infringements of intellectual property rights in trade relations are outlined.

The effectiveness of the EU trade policy, which is determined by the dynamics of exports and imports of goods and services both in foreign markets and in the Common Market of the integration group, is assessed. The conducted statistical analysis allowed to determine: (i) EU leading positions in foreign markets (second place in trade in goods and first place in trade in services) under the condition of positive dynamics of exports and imports of goods and services in 2010-2019; (ii) the predominance through trade convergence processes in national exports and imports of goods of the share of trade relations with member countries of the community (over 50\%); (iii) the main manifestations of trade divergence appear in the dominance of 5 countries in export-import relations in the domestic market, significant differentiation in the growth rates of exports and imports of goods in trade in the domestic market, and so on.

The obtained results allow to state a significant effect of convergence of EU member states due to the transformation of Community trade policy and development of the Common Market for almost all EU-27 countries.
\end{abstract}

Keywords: European Union, trade policy, convergence, divergence, common market, export and import of goods.

Постановка проблеми. Загальновизнаним $є$ той факт, що торговельна політика $\epsilon$ рушійною силою інтеграційних процесів у світовій економіці, стрижнем поступального розвитку інтеграційних угруповань. Хрестоматійним прикладом еволюції торговельної політики в межах інтеграційного угруповання є поетапна реалізація в Європейському Союзі основних форм міжнародної економічної інтеграції (зони вільної торгівлі, митного союзу, спільного ринку, економічного союзу та повної інтеграції) і розбудова Спільного ринку. Формування єдиного економічного простору відбувалося в умовах безперервної трансформації нормативно-правового середовища i 
регламентації безперешкодного переміщення капіталу, товарів та послуг, робочої сили.

Природно, що інтеграційні процеси, у тому числі розширення кількісного складу країн-членів Свропейського Союзу (СС), мали як конвергентний, так i дивергентний характер. В цьому зв'язку науково-практичний інтерес для України представляє емпіричне оцінювання тенденцій конвергенції та дивергенції у торговельних відносинах країн-членів СС.

Аналіз останніх досліджень і публікацій. Дослідженню концептуальних засад і різнопланової проблематики конвергенції присвячено праці Р.Солоу, Т.Свана, Г.Менк’ю, Д.Ромера, Д.Уейла, Р.Барро, Г.Річардсона, П.Кругмана, Г.Мюрдаля, П.Ромера, Дж.Гросмана, Е.Хедпмана та ін. Серед вітчизняних вчених слід відзначити праці О.Борзенко і Т.Бурлай, О.Булатової, В.Вергуна, А.Гальчинського, Ю.Козака, Д.Лук’яненка, Ю.Пахомова, А.Поручника, О.Рогача, А.Філіпенка та ін.

Огляд науково-практичних публікацій 3 проблем оцінювання тенденцій конвергенції та дивергенції між окремими країнами дозволяє визначити, що переважна більшість дослідників обмежується використанням моделей економічного зростання і оцінюванням рівнів та динаміки ВВП і доходу на душу населення.

Серед праць, у яких оцінюються ефекти торговельної політики та Спільного ринку варто відмітити дослідження Балдвіна Р., Джозефа Ф. Франсуа та Порте Р. щодо оцінювання виграшів та втрат від інтеграції для країн Центральної та Східної Свропи і для країн ядра СС-15 [1]. Автори вважають, що розширення на Схід є чудовою угодою для всіх діючих країн ЄC-15 та надзвичайно корисним для країн Центральної та Східної Європи в довгостроковій перспективі. За допомогою глобальної моделі загальної рівноваги автори моделюють торгові ефекти, ефекти спільного ринку та ефекти руху капіталу для зазначених груп країн. За результатами дослідження вони відзначили, що вступ до ЄС зробить регіон суттєво менш ризикованим 3 позицій національних та іноземних інвесторів. До того ж членство в СС гарантує, що регіональні товари будуть мати повний доступ до ринків СС-15. 3 макро позиції членство може поставити регіон на відносно легкий шлях до валютного союзу і забезпечити надійний захист від стрибків інфляції. Поєднуючи економічні вигоди та бюджетні витрати, автори розглядають розширення на Схід як феноменально хорошу угоду для СС-15. За оцінками, бюджетні трансферти, за вирахуванням економічних вигод, не повинні перевищувати $0,1 \%$ ВВП СС-15.

Міхель Р. для обчислення конвергенції країн-членів СС використала різні групи показників, серед яких: 1. Спільний ринок СС (внутрішній експорт та імпорт товарів у відсотках до ВВП, внутрішній експорт та імпорт послуг у відсотках до ВВП, внутрішній обіг ПІІ у відсотках до ВВП). 2. Однорідність СС (ВВП, ПКС тощо). 3. Симетрія СС (економічне зростання, інфляція, безробіття, державні позики). 4. Членство СС (участь у Шенгенській угоді та зоні євро). 5. Соціальна політика СС [2]. Провівши кластерний аналіз 23 
економічних показників для ЄС-27, автор дійшла висновку, що економічна нерівність між новими та старими країнами-членами ЄС є достатньо високою та потребує багато зусиль і часу для вирівнювання (конвергенції). При цьому кількість кластерів та відстані між ними зменшуватимуться.

Попко Д. та Ткачук О., аналізуючи передінтеграційний досвід країн Центральної та Східної Свропи, виявили ефекти регіональної інтеграції, торгові ефекти, ефекти руху капіталу [3].

На нашу думку, зважаючи на важливість торговельної політики для розбудови Свропейського Союзу та реалізації політики розширення, ефекти конвергенції та дивергенції у торговельних відносинах країн-членів потребують окремого дослідження.

Метою статті $\epsilon$ систематизація основних напрямів трансформації торговельної політики Європейського Союзу, ідентифікація показників та аналіз динаміки процесів конвергенції й дивергенції у торговельних відносинах між країнами-членами й третіми країнами (інтеграційними угрупованнями).

\section{Виклад основного матеріалу.}

Систематизація основних напрямів трансформації спільної торговельної політики СС дозволила визначити наступне:

(i) на національному рівні країни-члени уніфікують митне законодавство, захисні торговельні заходи, зокрема щодо демпінгу та субсидування, технічного регулювання (квотування, ліцензування), фіто-санітарних норм, захисту інтелектуальної власності тощо;

(ii) на рівні угруповання політика концентрується на заходах і правилах торгівлі товарами в межах митної території СС, удосконаленні нормативноправової бази щодо створення та розвитку Єдиного ринку; узгоджується спільна позиція щодо регламентації торговельних відносин з третіми країнами та інтеграційними угрупованнями, реформування глобальної системи міжнародної торгівлі;

(iii) на міжнародному (глобальному) рівні $€ C$ виступає як єдине ціле і $\epsilon$ активним учасником багатосторонніх переговорів в рамках Світової організації торгівлі (СОТ), Всесвітньої митної організації (ВМО), Всесвітньої організації інтелектуальної власності (BOIB) та ін. Участь в міжнародних організаціях дозволяє ЄС відстоювати зовнішньоекономічні інтереси за допомогою лобіювання міжнародних норм, що відповідають інтересам європейських виробників. Особливий напрям торговельної політики ЄС формується на двосторонніх переговорах з третіми країнами та інтеграційними угрупованнями, інституційно закріплюється у формуванні Узагальненої системи преференцій (GSP), укладанні угод про зону вільної торгівлі та угод про асоціацію.

Окремі складові торговельної політики на міжнародному рівні стосуються й України. Так, наприклад, Рада Свропейського Союзу 11 травня 2020 року затвердила засади політики щодо країн «Східного партнерства» на період після 2020 року [4]. У своєму рішенні парламентарії заявили про прихильність створенню зони загальної демократії, процвітання і стабільності з країнами 
формату «Східного партнерства» (Україна, Молдова, Грузія, Білорусь, Азербайджан i Вірменія). Ключове значення у співпраці будуть мати розширення торгівлі, продовження нормативного зближення, створення умов для постійного зближення цих країн 3 внутрішнім ринком СС та поступової економічної інтеграції. Ці кроки будуть супроводжуватися усуненням торговельних бар'єрів і поліпшенням заходів безпеки харчових продуктів, санітарних і фітосанітарних заходів, продовженням реформ. При цьому, згідно даних Свростату, динаміка питомої ваги країн Східного партнерства у торгівлі товарами з СС-28 у 2010-2019 рр. практично не змінилася і не перевищує 2\% як в експорті, так і в імпорті, а питома вага України в 2019 р. досягла 1\% в імпорті та 1,2\% - в експорті [5].

Ще однією складової торговельної політики СС, що стосується України, $\epsilon$ протидія обігу продукції, що порушує права інтелектуальної власності європейських виробників. Для цього $Є С$ затвердив Стратегію застосування прав інтелектуальної власності в третіх країнах (Strategy for the enforcement of IP rights in third countries [6]). У Стратегії констатується, що сектор економіки, який містить права інтелектуальної власності, забезпечує 39\% ВВП ЄС і 35\% зайнятості населення спільноти. Втрати СС від обороту контрафактної продукції складають щорічно близько 8 млрд. євро. При цьому механізмів захисту прав інтелектуальної власності, передбачених нормами СОТ, недостатньо. У зв'язку з цим впроваджується система заходів, спрямована на підвищення ефективності зазначених механізмів в третіх країнах: визначення пріоритетних країн на основі проведеного дослідження ситуації в сфері захисту прав інтелектуальної власності в різних регіонах світу; посилення роботи щодо захисту прав інтелектуальної власності в багатосторонніх форматах, зокрема в рамках Угоди про торговельні аспекти прав інтелектуальної власності (TRIPS Agreement), а також в форматі двостороннього співробітництва (цілий ряд двосторонніх угод $\mathrm{CC} \mathrm{містить} \mathrm{главу,} \mathrm{присвячену} \mathrm{питанням} \mathrm{захисту} \mathrm{прав}$ інтелектуальної власності).

Україна входить до другої категорії Списку пріоритетного спостереження $€ \mathrm{C}$, який включає країни з найбільш серйозними проблемами в сфері захисту інтелектуальної власності [7]. Разом з Україною в 2021 р. в другу категорію потрапили Індія, Росія і Туреччина. Укладачі звіту у відповідному розділі звіту, присвяченому Україні, найголовнішими проблемами в сфері авторських прав називають транзит контрафактної та піратської продукції на ринки Євросоюзу i онлайн-піратство. Також наводяться проблеми, пов'язані 3 механізмами реєстрації торгових марок, недосконалістю митних процедур, проблеми в сфері визначення кабельної ретрансляції та відповідних тарифів і відсутність належного контролю за так званими «дженериками» - медичними препаратами, які копіюють оригінальну продукцію відомих брендів. Наголошується на невідповідності деяких зареєстрованих законопроектів чинному законодавству СС.

Стосовно перспектив трансформації торговельної політики $\mathrm{CC}$ варто відмітити положення «Нового порядку денного СС та США щодо глобальних 
змін» (A new EU-US agenda for global change, 2.12.2020) та «стратегії стимулювання відкритості, сили та стійкості економічної та фінансової системи ЄС на наступні роки» (Commission takes further steps to foster the openness, strength and resilience of Europe's economic and financial system, 19 January 2021).

Ефекти конвергенції i дивергенції торговельної політики $€ C$ визначаються динамікою експорту та імпорту товарів і послуг як на зовнішніх ринках, так і на Спільному ринку інтеграційного угруповання.

За даними Світової організації торгівлі ЄС-27 посідає другу позицію серед провідних суб'єктів міжнародної торгівлі товарами і перше місце - у торгівлі послугами (виключаючи торгівлю всередині ЄС) [8, p. 128-129]. Середньорічний приріст у 2010-2019 рр. склав в експорті товарів - 3\% і досяг 2,387 трлн. дол. США, в імпорті - 1\% і досяг 2,163 трлн. дол. США. Питома вага ЄС в 2019 р. у світовому експорті товарів склала 12,62\%, в імпорті 11,24\%. У світовій торгівлі послугами середньорічний приріст у 2010-2019 рр. для ЄС склав як в експорті, так і в імпорті - 5\%, а питома вага об'єднання у 2019 р. досягла, відповідно, - 18,52\% (понад 1,123 трлн дол. США) та 17,63\% (понад 1,01 трлн дол. США). Серед основних торговельних партнерів в експорті товарів - США (18\%), Великобританія (15\%), Китай $(9,3 \%)$, Швейцарія (6,9\%) і Росія (4,1\%), в імпорті товарів - Китай $(18,7 \%)$, США $(12 \%)$, Великобританія $(10 \%)$, Росія $(7,4 \%)$ та Швейцарія $(5,7 \%)$. Серед топ-5 торговельних партнерів в експорті послуг - Великобританія (21,8\%), США (18,8\%), Швейцарія (10,9\%), Китай (4,8\%) та Японія (2,8\%), в імпорті товарів США $(23,2 \%)$, Великобританія (18,8\%), Швейцарія $(6,9 \%)$, Китай $(3,4 \%)$ та Індія $(1,8 \%)[8]$.

При цьому, згідно даних Свростату, у 2020 р. експорт товарів на зовнішні ринки ЄС впав на 9,4\% до 1931,6 млрд. євро порівняно 32019 р., а імпорт - на 11,6\% до 1 714,3 млрд. євро. Торгівля всередині СС в 2020 р. скоротилася лише на 7,5\% до 2841,7 млрд. євро порівняно 32019 р. [9]. Наведені дані підкреслюють важливість Спільного (внутрішнього) ринку СС у розвитку торгівлі товарами.

Оцінювання ефектів торговельної політики СС країн Свросоюзу здійснено шляхом аналізу динаміки основних показників, які характеризують зовнішньоторговельні відносини всередині спільноти та на зовнішніх ринках.

Ключовим показником ефективності торговельної політики та створення Спільного ринку є зростання показника експорту товарів на внутрішній ринок ЄС у вартісному обчисленні, що є свідченням посилення конвергенції. Зокрема приріст експорту 27 країн СС (без Великобританіï) за період 2008-2019 рр. склав 133,2\% і оцінюється у понад 3 трлн. євро. При цьому, як свідчать дані табл. 1, нарощування експорту окремими країнами відбувалося вкрай нерівномірними темпами. Природно, що вищи показники приросту експорту на внутрішній ринок протягом зазначеного періоду продемонстрували країни, які увійшли до спільноти після 2004 року: найвищі величини показника зафіксовані для Румунії (майже 221\%), Болгарії (понад 214\%) та Польщі (210\%). До цієї групи з 13 країн щільно примкнули відносно «слабкі» країни - 
Португалія (+158\%), Іспанія та Греція (+149\%). Нижчий за середній по СС-27 приріст експорту продемонстрували потужні економіки спільноти - Німеччина та Франція. Єдиною країною, для якої приріст експорту на внутрішній ринок виявився меншим за 100\%, є Люксембург. Проте, якщо взяти за точку відліку 2010 рік, цей показник буде більшим за 100\%, що свідчитиме про позитивну динаміку поставок на внутрішній ринок.

Таблиия 1

\section{Динаміка експорту товарів країн ЄС-27 на внутрішній ринок}

у 2008-2019 рр., млн. євро

\begin{tabular}{|c|c|c|c|c|c|c|c|}
\hline (3 2020) & 2008 & 2010 & 2012 & 2014 & 2016 & 2019 & $\begin{array}{c}\text { Приріст } \\
2019 / 2008 \\
\end{array}$ \\
\hline СС - 27 країн & 2306759,4 & $\begin{array}{l}2162 \\
091,3\end{array}$ & 2384910,8 & 2459399,5 & 2624149,1 & 3071560,5 & 133,2 \\
\hline Румунія & 22751,9 & 25746,8 & 30084,4 & 35160,7 & 40590,4 & 50255,4 & 220,9 \\
\hline Болгарія & 8925,9 & 9248,3 & 11839,1 & 13275,7 & 15339,7 & 19115,7 & 214,2 \\
\hline Польща & 83863,7 & 88015,8 & 100199,4 & 117728,4 & 134559,5 & 176149,1 & 210,0 \\
\hline Латвія & 4493,8 & 4606,2 & 6659,2 & 7131,3 & 7200,0 & 8714,4 & 193,9 \\
\hline Кіпр & 654,5 & 614,8 & 693,6 & 1026,6 & 980,7 & 1250,6 & 191,1 \\
\hline Мальта & 790,1 & 986,2 & 1168,1 & 1004,8 & 1115,6 & 1440,6 & 182,3 \\
\hline Литва & 8959,1 & 8783,9 & 12482,7 & 12440,1 & 12758,6 & 16302,1 & 182,0 \\
\hline Хорватія & 5613,8 & 5307,1 & 5450,6 & 6466,4 & 8009,5 & 10154,9 & 180,9 \\
\hline Чехія & 80445,7 & 79657,2 & 93527,7 & 101692,0 & 115231,3 & 141294,5 & 175,6 \\
\hline Естонія & 5711,4 & 5826,3 & 8004,6 & 8444,3 & 8509,9 & 9871,4 & 172,8 \\
\hline Словенія & 17243,6 & 16631,1 & 18312,6 & 19903,4 & 21838,0 & 28905,3 & 167,6 \\
\hline Словаччина & 39258,8 & 40435,3 & 50317,1 & 51490,5 & 55679,5 & 63932,4 & 162,8 \\
\hline Португалія & 26802,1 & 26077,6 & 29740,0 & 31100,9 & 34051,3 & 42367,4 & 158,1 \\
\hline Угорщина & 55398,9 & 52579,7 & 59074,5 & 63506,5 & 71295,7 & 86778,7 & 156,6 \\
\hline Іспанія & 119860,5 & 119935,8 & 131754,4 & 138822,0 & 154399,2 & 178369,1 & 148,8 \\
\hline Греція & 11933,5 & 10617,6 & 11370,0 & 12123,4 & 13257,1 & 17743,7 & 148,7 \\
\hline Ірландія & 38025,6 & 37476,7 & 39667,6 & 36508,7 & 44452,4 & 56207,0 & 147,8 \\
\hline Нідерланди & 304621,8 & 302002,2 & 346552,5 & 340155,3 & 342734,9 & 413651,3 & 135,8 \\
\hline Австрія & 86690,4 & 79603,7 & 87236,7 & 89661,7 & 92833,4 & 108308,3 & 124,9 \\
\hline Німеччина & 561533,2 & 514283,2 & 548730,6 & 569476,2 & 619851,1 & 698459,9 & 124,4 \\
\hline Італія & 201011,7 & 177947,0 & 192910,8 & 197884,5 & 210996,3 & 245447,2 & 122,1 \\
\hline Бельгія & 223684,1 & 203098,6 & 218540,2 & 221138,6 & 227166,9 & 259816,6 & 116,2 \\
\hline Швеція & 65867,9 & 59581,9 & 66136,8 & 63576,0 & 66857,2 & 75251,4 & 114,2 \\
\hline Франція & 236148,1 & 214577,0 & 231180,7 & 232326,1 & 237473,8 & 262092,3 & 111,0 \\
\hline Фінляндія & 33134,5 & 26101,2 & 27650,1 & 29043,1 & 28183,1 & 35918,8 & 108,4 \\
\hline Данія & 49020,6 & 41888,3 & 44844,5 & 46886,6 & 47520,7 & 52029,7 & 106,1 \\
\hline Люксембург & 14314,1 & 10461,8 & 10782,3 & 11425,4 & 11263,4 & 11732,7 & 82,0 \\
\hline
\end{tabular}

Джерело: Складено і проранжовано автором за даними Свростату: Intra-EU27 (from 2020) trade, by Member State, total product [TET00011]. Exports in million of ECU/EURO

Важливість Спільного ринку практично для усіх країн ЄС-27 визначається величиною показника питомої ваги експорту товарів на внутрішній ринок у загальному експорті товарів країни-члена (табл. 2). Так, лише для Кіпру (40,6\%) та Ірландії $(37,1 \%)$ цей показник є меншим за 50\%. Однак, величина цього показника для ЄС-27 в цілому має коливальну тенденцію з переважанням незначного зменшення - 3 61,9\% у 2008 р. до 59\% у 
2019 р. Для 8 країн поставки товарів на Спільний ринок складають 7080\% національного експорту. а для 11 країн величина показника є нижчою за середню для $\mathrm{EC}-27$.

Таблиияя 2

Динаміка питомої ваги експорту товарів країн ЄС-27 на внутрішній ринок у загальному експорті у 2008-2019 рр., \%

\begin{tabular}{|l|c|c|c|c|c|c|c|}
\hline Країна & 2008 & 2010 & 2012 & 2014 & 2016 & 2018 & 2019 \\
\hline СС-27 країн & 61,9 & 60,1 & 57,4 & 57,8 & 58,4 & 59,4 & 59,0 \\
\hline Словаччина & 81,2 & 81,3 & 80,1 & 79,3 & 80,0 & 81,0 & 80,0 \\
\hline Люксембург & 81,9 & 73,8 & 73,6 & 79,3 & 79,0 & 81,0 & 79,9 \\
\hline Чехія & 80,6 & 79,4 & 76,5 & 77,2 & 78,4 & 79,7 & 79,4 \\
\hline Угорщина & 75,1 & 73,0 & 73,3 & 76,3 & 77,4 & 78,0 & 78,5 \\
\hline Польща & 72,4 & 73,1 & 69,4 & 71,0 & 73,1 & 74,3 & 74,0 \\
\hline Румунія & 67,6 & 68,8 & 66,8 & 67,0 & 70,7 & 72,8 & 73,2 \\
\hline Словенія & 74,3 & 75,5 & 73,2 & 73,5 & 73,4 & 74,6 & 72,0 \\
\hline Португалія & 69,0 & 70,0 & 65,8 & 64,7 & 68,0 & 69,8 & 70,7 \\
\hline Естонія & 67,4 & 66,6 & 63,9 & 69,9 & 71,5 & 65,8 & 68,6 \\
\hline Австрія & 70,3 & 69,2 & 67,3 & 66,8 & 67,6 & 68,6 & 67,9 \\
\hline Хорватія & 58,6 & 59,6 & 56,6 & 62,0 & 64,1 & 66,3 & 66,2 \\
\hline Нідерланди & 70,2 & 69,7 & 67,9 & 67,2 & 66,4 & 66,0 & 65,3 \\
\hline Бельгія & 69,7 & 66,0 & 63,0 & 62,2 & 63,1 & 65,1 & 65,1 \\
\hline Болгарія & 58,7 & 59,4 & 57,0 & 60,2 & 63,9 & 65,2 & 64,2 \\
\hline Латвія & 65,2 & 64,1 & 60,6 & 64,3 & 64,8 & 61,4 & 62,1 \\
\hline Іспанія & 62,6 & 62,5 & 57,3 & 56,8 & 58,9 & 59,5 & 59,8 \\
\hline Литва & 55,7 & 56,1 & 54,2 & 51,1 & 56,4 & 55,0 & 55,0 \\
\hline Фінляндія & 50,5 & 49,8 & 48,6 & 51,9 & 53,9 & 54,5 & 54,7 \\
\hline Мальта & 33,4 & 36,5 & 35,3 & 45,6 & 38,7 & 53,2 & 53,6 \\
\hline Данія & 61,7 & 57,6 & 53,8 & 55,9 & 55,2 & 54,3 & 52,6 \\
\hline Німеччина & 57,1 & 54,2 & 50,3 & 50,6 & 51,4 & 52,7 & 52,5 \\
\hline Швеція & 52,8 & 49,8 & 49,3 & 51,3 & 53,1 & 53,8 & 52,5 \\
\hline Греція & 56,2 & 50,2 & 41,4 & 44,8 & 52,1 & 49,2 & 52,4 \\
\hline Франція & 56,4 & 54,3 & 52,2 & 53,1 & 52,4 & 52,3 & 51,4 \\
\hline Італія & 54,5 & 52,7 & 49,4 & 49,6 & 50,6 & 51,4 & 51,1 \\
\hline Кіпр & 58,9 & 58,1 & 51,2 & 43,3 & 36,6 & 25,5 & 40,6 \\
\hline Ірландія & 44,5 & 42,3 & 42,9 & 40,0 & 37,6 & 38,8 & 37,1 \\
\hline
\end{tabular}

Джерело: Складено i проранжовано автором за даними Євростату:Eurostat EXT_LT_INTERTRD Share of trade with the EU27 (from 2020) [TET00037]. Share of exports to EU in total exports $(\%)$.

У імпорті країн ЄС 3 внутрішнього ринку динаміка відповідних показників також свідчить про конвергентні процеси не меншої значущості. Так, приріст імпорту для ЄС-27 в цілому склав 133,9\% з 2008 по 2019 рр., що є на 0,7\% вищим у порівнянні з аналогічним показником по експорту (табл. 3). При цьому серед країн-лідерів при ранжуванні за цим показником - «старі» члени $\mathrm{CC,} \mathrm{зокрема} \mathrm{Ірландія} \mathrm{(1} \mathrm{місце,} \mathrm{приріст} \mathrm{187,1 \% ),} \mathrm{Німеччина} \mathrm{(11} \mathrm{місце,}$ приріст 147,3\%), Нідерланди (14 місце, приріст 137\%). Сдиною країною, яка зменшила імпорт з внутрішнього ринку СС, виявилася Греція, для якої приріст склав лише $82 \%$. 
Табличя 3

Динаміка імпорту товарів країн ЄС-27 з внутрішнього ринку у 2008-2019 рр., млн. свро

\begin{tabular}{|c|c|c|c|c|c|c|c|}
\hline Країна & 2008 & 2010 & 2012 & 2014 & 2016 & 2019 & $\begin{array}{c}\text { Приріст } \\
2019 / 2008 \\
\end{array}$ \\
\hline $\begin{array}{l}\text { EC-27 } \\
\text { країн }\end{array}$ & 2248876,1 & 2099688,5 & 2324833,4 & 2400822,0 & 2574762,0 & 3010409,5 & 133,9 \\
\hline Ірландія & 18405,9 & 14401,7 & 16341,4 & 20761,0 & 27465,6 & 34437,4 & 187,1 \\
\hline Литва & 11776,7 & 9712,1 & 13788,1 & 15890,4 & 16900,8 & 21205,0 & 180,1 \\
\hline Словаччина & 36106,1 & 35475,1 & 43662,4 & 46221,0 & 53142,8 & 63445,4 & 175,7 \\
\hline Чехія & 71693,1 & 69023,5 & 80393,2 & 86999,1 & 98164,1 & 118329,2 & 165,1 \\
\hline Румунія & 38779,5 & 32951,3 & 38945,0 & 42795,5 & 50414,2 & & \\
\hline Поль & 3151,4 & 130,7 & & 112711,0 & & & \\
\hline Угорщи & & 44 & & 57 & & & \\
\hline Латвія & & 50,9 & 78,0 & 10 & 7,4 & & \\
\hline Хорв & 12958,5 & 8867,7 & 9896,3 & 12853,2 & 013,0 & & 152,8 \\
\hline Болгарія & 13954,7 & 10988,8 & 14594,8 & 15668,0 & 16778,4 & 583,5 & 147,5 \\
\hline Німеччина & 472000,5 & 466990,8 & 529752,5 & 554967,3 & 593098,5 & 695173,4 & 147,3 \\
\hline Естонія & 8381,0 & 7196,9 & 10406,3 & 10825,1 & 10713,3 & 12203,6 & 145,6 \\
\hline Мальта & 2297,1 & 2322,2 & 3588,1 & 2827,7 & 2878,3 & 3333,6 & 145,1 \\
\hline Ніде & 167170,1 & 157741,7 & 177267,6 & 176660,0 & 188205,2 & 229103,8 & 137,0 \\
\hline Слов & & & 17655,4 & 17349,1 & & & \\
\hline & & & & 102 & & & \\
\hline ШвеІ & 7,8 & 8,7 & 09,7 & 76 & 5,9 & & 129,2 \\
\hline Порт & 88,2 & 42585,3 & 19,9 & 42324,7 & 46014,7 & 90,5 & 128,6 \\
\hline Фінляндія & 36137,2 & 31672,9 & 35530,1 & 37535,8 & 38449,1 & 45400,8 & 125,6 \\
\hline Італія & 198270,0 & 192858,2 & 193091,1 & 193607,7 & 212082,7 & 241670,5 & 121,9 \\
\hline Франція & 308023,3 & 292508,1 & 325919,5 & 324942,4 & 335811,3 & 372629,2 & 121,0 \\
\hline Данія & 49527,0 & 40055,8 & 46293,3 & 48530,9 & 51918,4 & 58196,3 & 117,5 \\
\hline Іспанія & 156071,9 & 133345,8 & 131426,3 & 142949,8 & 161542,0 & 181934,9 & 116,6 \\
\hline Люксембург & & & & & & & \\
\hline Кіпр & & 4022,7 & & & & & 112,5 \\
\hline Бельгія & 203674,4 & 187463,9 & 212373,7 & 205119,4 & 202310,5 & 228814,8 & 112,3 \\
\hline Греція & 34610,8 & 25923,3 & 21643,9 & 22057,4 & 22925,1 & 28565,8 & 82,5 \\
\hline
\end{tabular}

Джерело: Складено і проранжовано автором за даними Свростату: Intra-EU27 (from 2020) trade, by Member State, total product [TET00011]. Imports in million of ECU/EURO.

Динаміка питомої ваги імпорту товарів країн СС-27 з внутрішнього ринку у загальному імпорті у 2008-2019 рр. також є вищою, ніж для аналогічного показника по експорту, а його величина у 2019 р. для ЄС-27 є вищою на 1,8 \% табл. 4). При ранжуванні за цим показником 2019 р. серед країн-лідерів також $\epsilon$ «старі» члени $\mathrm{CC}$, зокрема Люксембург (1 місце, 83,4\%), Австрія (4 місце, $76,2 \%$ ), Португалія (8 місце, 73,8\%) та ін. Двома країнами, для яких імпорт 3 країн ЄС-27 є меншим за 50\% у загальному обсязі імпорту товарів, $є$ Нідерланди (40,3\%) та Ірландія (38,3\%). 
Динаміка питомої ваги імпорту товарів країн СС-27 з внутрішнього ринку у загальному імпорті у 2008-2019 рр., \%

\begin{tabular}{|l|c|c|c|c|c|c|c|}
\hline Країна & 2008 & 2010 & 2012 & 2014 & 2016 & 2018 & 2019 \\
\hline СС - 27 країн & 59,1 & 58,8 & 57,7 & 59,6 & 61,6 & 60,7 & 60,8 \\
\hline Люксембург & 73,3 & 79,1 & 75,8 & 78,8 & 76,3 & 86,6 & 83,4 \\
\hline Словаччина & 71,8 & 70,6 & 72,5 & 75,3 & 78,8 & 78,5 & 78,9 \\
\hline Хорватія & 62,2 & 58,6 & 61,0 & 74,9 & 75,9 & 76,4 & 78,7 \\
\hline Австрія & 77,0 & 76,6 & 75,0 & 75,1 & 76,2 & 75,8 & 76,2 \\
\hline Естонія & 76,9 & 77,7 & 73,9 & 78,6 & 79,3 & 74,0 & 75,8 \\
\hline Латвія & 74,0 & 74,3 & 75,9 & 78,0 & 78,0 & 72,1 & 74,9 \\
\hline Чехія & 74,2 & 72,2 & 73,0 & 74,9 & 75,9 & 74,3 & 74,0 \\
\hline Португалія & 71,5 & 72,6 & 68,5 & 71,7 & 74,9 & 73,4 & 73,8 \\
\hline Румунія & 67,9 & 70,3 & 71,3 & 73,1 & 74,8 & 72,6 & 72,7 \\
\hline Угорщина & 66,6 & 66,2 & 68,8 & 73,4 & 75,7 & 72,8 & 71,9 \\
\hline Фінляндія & 57,9 & 61,0 & 59,7 & 65,0 & 69,9 & 67,6 & 68,9 \\
\hline Данія & 66,6 & 63,9 & 64,8 & 64,7 & 67,2 & 66,4 & 66,6 \\
\hline Польща & 69,1 & 67,9 & 65,2 & 66,9 & 69,6 & 67,4 & 66,5 \\
\hline Литва & 55,7 & 55,0 & 55,4 & 61,4 & 68,3 & 66,1 & 66,4 \\
\hline Швеція & 62,9 & 61,5 & 60,8 & 62,6 & 65,9 & 65,0 & 65,5 \\
\hline Франція & 63,2 & 63,5 & 62,1 & 63,8 & 65,4 & 64,5 & 63,7 \\
\hline Німеччина & 58,6 & 58,7 & 58,9 & 61,1 & 62,2 & 62,7 & 63,1 \\
\hline Словенія & 74,1 & 71,4 & 70,8 & 67,9 & 69,6 & 66,0 & 62,2 \\
\hline Болгарія & 55,6 & 57,1 & 57,3 & 60,0 & 64,1 & 62,1 & 61,2 \\
\hline Бельгія & 64,2 & 63,5 & 62,1 & 60,1 & 59,0 & 60,0 & 59,9 \\
\hline Кіпр & 59,3 & 62,2 & 61,8 & 58,2 & 60,7 & 51,0 & 59,2 \\
\hline Італія & 51,9 & 52,5 & 50,8 & 54,2 & 57,7 & 56,2 & 57,0 \\
\hline Іспанія & 54,6 & 54,1 & 50,1 & 52,9 & 57,5 & 54,7 & 54,6 \\
\hline Мальта & 63,7 & 60,8 & 69,9 & 55,1 & 49,5 & 63,1 & 52,8 \\
\hline Греція & 52,8 & 52,2 & 45,1 & 47,2 & 54,2 & 50,1 & 51,2 \\
\hline Нідерланди & 42,3 & 40,8 & 38,8 & 39,8 & 41,6 & 40,2 & 40,3 \\
\hline Ірландія & 32,2 & 30,2 & 29,8 & 33,6 & 37,4 & 38,0 & 38,3 \\
\hline
\end{tabular}

Джерело: Складено і проранжовано автором за даними Свростату: Share of trade with the EU27 (from 2020) [TET00037]EXT_LT_INTERTRD. Share of imports from EU in total imports (\%).

Розшарування (дивергенція) країн ЄС-27 проявляється у потенціалі експортно-імпортних операцій товарами на внутрішньому ринку. Так на 5 «старих» країн спільноти (Німеччину, Нідерланди, Бельгію, Францію та Італію) доводиться понад $60 \%$ загального обсягу експорту на внутрішній ринок (табл. 5), однак для більшості з них величини показника зменшилися. Високі темпи зростання питомої ваги експорту країни у загальному обсязі експорту на внутрішній ринок демонструють Польща (7 місце, зростання показника з 3,6\% в 2008 р. до 5,7\% в 2019 р.), Чехія (8 місце, 3,5\% та 4,6\%, відповідно) та Угорщина (10 місце, 2,4\% та 2,8\%, відповідно). 
Динаміка питомої ваги експорту товарів країн ЄС-27 у загальному обсязі експорту на внутрішньому ринку у 2008-2019 рр., \%

\begin{tabular}{|c|c|c|c|c|c|c|c|}
\hline & & & & & & & \\
\hline & 2008 & 2010 & 2012 & 2014 & 2016 & 2018 & 2019 \\
\hline СС - 27 країн & 100,0 & 100,0 & 100,0 & 100,0 & 100,0 & 100,0 & 100,0 \\
\hline Німеччина & 24,3 & 23,8 & 23,0 & 23,2 & 23,6 & 23,1 & 22,7 \\
\hline Нідерланди & 13,2 & 14,0 & 14,5 & 13,8 & 13,1 & 13,5 & 13,5 \\
\hline Бельгія & 9,7 & 9,4 & 9,2 & 9,0 & 8,7 & 8,6 & 8,5 \\
\hline Франція & 10,2 & 9,9 & 9,7 & 9,4 & 9,0 & 8,6 & 8,5 \\
\hline Італія & 8,7 & 8,2 & 8,1 & 8,0 & 8,0 & 7,9 & 8,0 \\
\hline Іспанія & 5,2 & 5,5 & 5,5 & 5,6 & 5,9 & 5,8 & 5,8 \\
\hline Польща & 3,6 & 4,1 & 4,2 & 4,8 & 5,1 & 5,5 & 5,7 \\
\hline Чехія & 3,5 & 3,7 & 3,9 & 4,1 & 4,4 & 4,5 & 4,6 \\
\hline Австрія & 3,8 & 3,7 & 3,7 & 3,6 & 3,5 & 3,6 & 3,5 \\
\hline Угорщина & 2,4 & 2,4 & 2,5 & 2,6 & 2,7 & 2,7 & 2,8 \\
\hline Швеція & 2,9 & 2,8 & 2,8 & 2,6 & 2,5 & 2,5 & 2,4 \\
\hline Словаччина & 1,7 & 1,9 & 2,1 & 2,1 & 2,1 & 2,1 & 2,1 \\
\hline Ірландія & 1,6 & 1,7 & 1,7 & 1,5 & 1,7 & 1,8 & 1,8 \\
\hline Данія & 2,1 & 1,9 & 1,9 & 1,9 & 1,8 & 1,7 & 1,7 \\
\hline Румунія & 1,0 & 1,2 & 1,3 & 1,4 & 1,5 & 1,6 & 1,6 \\
\hline Португалія & 1,2 & 1,2 & 1,2 & 1,3 & 1,3 & 1,3 & 1,4 \\
\hline Фінляндія & 1,4 & 1,2 & 1,2 & 1,2 & 1,1 & 1,2 & 1,2 \\
\hline Словенія & 0,7 & 0,8 & 0,8 & 0,8 & 0,8 & 0,9 & 0,9 \\
\hline Греція & 0,5 & 0,5 & 0,5 & 0,5 & 0,5 & 0,5 & 0,6 \\
\hline Болгарія & 0,4 & 0,4 & 0,5 & 0,5 & 0,6 & 0,6 & 0,6 \\
\hline Литва & 0,4 & 0,4 & 0,5 & 0,5 & 0,5 & 0,5 & 0,5 \\
\hline Люксембург & 0,6 & 0,5 & 0,5 & 0,5 & 0,4 & 0,4 & 0,4 \\
\hline Естонія & 0,2 & 0,3 & 0,3 & 0,3 & 0,3 & 0,3 & 0,3 \\
\hline Хорватія & 0,2 & 0,2 & 0,2 & 0,3 & 0,3 & 0,3 & 0,3 \\
\hline \begin{tabular}{|l|} 
Латвія \\
\end{tabular} & 0,2 & 0,2 & 0,3 & 0,3 & 0,3 & 0,3 & 0,3 \\
\hline Кіпр & 0,0 & 0,0 & 0,0 & 0,0 & 0,0 & 0,0 & 0,0 \\
\hline Мальта & 0,0 & 0,0 & 0,0 & 0,0 & 0,0 & 0,0 & 0,0 \\
\hline
\end{tabular}

Джерело: Складено і проранжовано автором за даними Євростату: Intra-EU27 (from 2020) trade, by Member State, total product [TET00011]. Share of exports by Member State (\%)

Питома вага 5 «старих» країн спільноти (Німеччини, Франції, Італії, Бельгії та Нідерландів) у загальному обсязі імпорту у торгівлі товарами на Спільному ринку склала у 2019 р. близько 59\% (табл. 6). Високі темпи нарощування питомої ваги імпорту країни у загальному обсязі імпорту 3 внутрішнього ринку демонструють Польща (7 місце, зростання показника 3 4,4\% в 2008 р. до 5,2\% в 2019 р.), Чехія (9 місце, 3,2\% та 3,9\%, відповідно) та Угорщина (11 місце, 2,2\% та 2,6\%, відповідно). 
Динаміка питомої ваги імпорту товарів країн ЄС-27 у загальному обсязі імпорту з внутрішнього ринку у 2008-2019 рр., \%

\begin{tabular}{|l|c|c|c|c|c|c|c|}
\hline & $\mathbf{2 0 0 8}$ & $\mathbf{2 0 1 0}$ & $\mathbf{2 0 1 2}$ & $\mathbf{2 0 1 4}$ & $\mathbf{2 0 1 6}$ & $\mathbf{2 0 1 8}$ & $\mathbf{2 0 1 9}$ \\
\hline СС - 27 країн & 100,0 & 100,0 & 100,0 & 100,0 & 100,0 & 100,0 & 100,0 \\
\hline Німеччина & 21,0 & 22,2 & 22,8 & 23,1 & 23,0 & 23,0 & 23,1 \\
\hline Франція & 13,7 & 13,9 & 14,0 & 13,5 & 13,0 & 12,5 & 12,4 \\
\hline Італія & 8,8 & 9,2 & 8,3 & 8,1 & 8,2 & 8,1 & 8,0 \\
\hline Бельгія & 9,1 & 8,9 & 9,1 & 8,5 & 7,9 & 7,8 & 7,6 \\
\hline Нідерланди & 7,4 & 7,5 & 7,6 & 7,4 & 7,3 & 7,4 & 7,6 \\
\hline Іспанія & 6,9 & 6,4 & 5,7 & 6,0 & 6,3 & 6,1 & 6,0 \\
\hline Польща & 4,4 & 4,3 & 4,3 & 4,7 & 4,9 & 5,2 & 5,2 \\
\hline Австрія & 4,3 & 4,4 & 4,5 & 4,3 & 4,2 & 4,2 & 4,2 \\
\hline Чехія & 3,2 & 3,3 & 3,5 & 3,6 & 3,8 & 3,9 & 3,9 \\
\hline Швеція & 3,2 & 3,3 & 3,3 & 3,2 & 3,3 & 3,2 & 3,1 \\
\hline Угорщина & 2,2 & 2,1 & 2,2 & 2,4 & 2,5 & 2,5 & 2,6 \\
\hline Словаччина & 1,6 & 1,7 & 1,9 & 1,9 & 2,1 & 2,1 & 2,1 \\
\hline Румунія & 1,7 & 1,6 & 1,7 & 1,8 & 2,0 & 2,0 & 2,1 \\
\hline Португалія & 2,0 & 2,0 & 1,7 & 1,8 & 1,8 & 1,9 & 2,0 \\
\hline Данія & 2,2 & 1,9 & 2,0 & 2,0 & 2,0 & 1,9 & 1,9 \\
\hline Фінляндія & 1,6 & 1,5 & 1,5 & 1,6 & 1,5 & 1,5 & 1,5 \\
\hline Ірландія & 0,8 & 0,7 & 0,7 & 0,9 & 1,1 & 1,2 & 1,1 \\
\hline Греція & 1,5 & 1,2 & 0,9 & 0,9 & 0,9 & 0,9 & 0,9 \\
\hline Словенія & 0,8 & 0,8 & 0,8 & 0,7 & 0,7 & 0,8 & 0,8 \\
\hline Литва & 0,5 & 0,5 & 0,6 & 0,7 & 0,7 & 0,7 & 0,7 \\
\hline Болгарія & 0,6 & 0,5 & 0,6 & 0,7 & 0,7 & 0,7 & 0,7 \\
\hline Хорватія & 0,6 & 0,4 & 0,4 & 0,5 & 0,6 & 0,6 & 0,7 \\
\hline Люксембург & 0,7 & 0,7 & 0,7 & 0,7 & 0,6 & 0,6 & 0,6 \\
\hline Латвія & 0,4 & 0,3 & 0,4 & 0,4 & 0,4 & 0,4 & 0,4 \\
\hline Естонія & 0,4 & 0,3 & 0,4 & 0,5 & 0,4 & 0,4 & 0,4 \\
\hline Кіпр & 0,2 & 0,2 & 0,2 & 0,1 & 0,2 & 0,2 & 0,2 \\
\hline Мальта & 0,1 & 0,1 & 0,2 & 0,1 & 0,1 & 0,1 & 0,1 \\
\hline
\end{tabular}

Джерело: Складено і проранжовано автором за даними Євростату: Intra-EU27 (from 2020) trade, by Member State, total product [TET00011 Share of imports by Member State (\%).

За підсумками 2019 р. 17 із 27 країн ЄС мають від’ємне сальдо торговельного балансу у торгівлі товарами на Спільному ринку, 10 країн - позитивне. Найбільше від'ємне сальдо мають Франція (понад 110 млрд. євро), Швеція (17,8 млрд. євро) та Австрія (17,4 млрд. євро). Найбільше позитивне сальдо мають Нідерланди (понад 184 млрд. євро), Бельгія (31 млрд. євро) та Чехія (майже 23 млрд. євро). 327 країн лише трьом вдалося протягом 2008-2019 років змінити негативне сальдо на позитивне Польщі, Словенії та Італії [10].

Висновки. Загальновизнаним $\epsilon$ той факт, що торговельна політика $\epsilon$ рушійною силою інтеграційних процесів у світовій економіці, стрижнем поступального розвитку інтеграційних угруповань. Спільна торговельна політика ЄС трансформується переважно через зміни регулятивного (нормативно-правового) середовища на національному рівні, на рівні угруповання й на глобальному рівні.

Ефективність торговельної політики ЄС визначається динамікою експорту та імпорту товарів і послуг як на зовнішніх ринках, так і на Спільному ринку 
інтеграційного угруповання, про що свідчить проведений аналіз динаміки експортно-імпортних операцій у міжнародній торгівлі та у торгівлі товарами на внутрішньому ринку.

Результати проведеного статистичного аналізу за авторською методикою дозволяють визнати переважання процесів конвергенції та високий ефект торгівлі товарами між країнами-членами на Спільному ринку. Певні ознаки дивергенції мають тенденції домінування потужних країн за показником питомої ваги у обсягах експорту та імпорту на внутрішньому ринку та динаміці сальдо торговельного балансу.

\section{Jimepamypa:}

1. Baldwin R. E., Joseph F. Francois, and Richard Portes. The costs and benefits of eastern enlargement: the impact on the EU and central Europe, Centre for Economic Policy Research, 1997. 52 p. Economic Policy No 24. URL: https://papers.ssrn.com/sol3/papers.cfm?abstract_ id $=513506$

2. Міхель Р. Процеси конвергенції між країнами-членами ЄС. Економіст. 2013. №2. C. 25-29.

3. Попко Д., Ткачук О. Моделювання конвергенції України до GC. URL: http://kneu.kiev.ua/journal/ukr/article/2005_2_PopkoTkachuk_ukr.pdf

4. Ткачук Б. Сближение и расширение торговли: Совет ЕС утвердил политику в отношении «Восточного партнерства» после 2020 года. 12 мая, 2020. URL: https://hromadske.ua/ru/posts/sblizhenie-i-rasshirenie-torgovli-sovet-es-utverdil-politiku-v-otnosheniivostochnogo-partnerstva-posle-2020-goda

5. Eurostat. Extra-EU trade by partner. URL: https://ec.europa.eu/eurostat/databrowser/ view/ext_lt_maineu/default/table?lang=en

6. COMMUNICATION FROM THE COMMISSION TO THE EUROPEAN PARLIAMENT, THE COUNCIL AND THE EUROPEAN ECONOMIC AND SOCIAL COMMITTEE. Trade, growth and intellectual property - Strategy for the protection and enforcement of intellectual property rights in third countries. /* COM/2014/0389 final */. URL: https://eur-lex.europa.eu/legal-content/EN/TXT/?uri=CELEX:52014DC0389

7. Report on the protection and enforcement of intellectual property rights in third countries. European Commission. Brussels, 27.4.2021 SWD(2021) 97 final. URL: https://trade.ec.europa.eu/ doclib/docs/2021/april/tradoc_159553.pdf

8. Trade Profiles 2020. World Trade Organization. 404 p. URL: www.wto.org/statistics

9. Euro area international trade in goods surplus $€ 29.2$ bn $€ 30.1$ bn surplus for EU. Eurostat. newsrelease22/2021 - 15 February 2021.

10. Eurostat. Intra-EU27 (from 2020) trade, by Member State, total product [TET00011]. Trade balance in million ECU/EURO.

\section{References:}

1. Baldwin R. E., Joseph F. Francois, and Richard Portes (1997). The costs and benefits of eastern enlargement: the impact on the EU and central Europe, Centre for Economic Policy Research. Economic Policy No 24. 52 p. Retrieved from https://papers.ssrn.com/sol3/papers.cfm?abstract_id=513506. [in English].

2. Mikhel' R.(2013). Protsesy konverhentsiyi mizh krayinamy-chlenamy YES. Ekonomist. №2. S. 25-29. [in Ukrainian].

3. Popko D., Tkachuk O. (2005). Modelyuvannya konverhentsiyi Ukrayiny do YES. Retrieved from http://kneu.kiev.ua/journal/ukr/article/2005_2_PopkoTkachuk_ukr.pdf. [in Ukrainian]. 
4. Tkachuk B. (2020). Sblizheniye i rasshireniye torgovli: Sovet YES utverdil politiku v otnoshenii «Vostochnogo partnerstva» posle 2020 goda. 12 maya. Retrieved from https://hromadske.ua/ru/posts/sblizhenie-i-rasshirenie-torgovli-sovet-es-utverdil-politiku-v-otnosheniivostochnogo-partnerstva-posle-2020-goda. [in Russian].

5. Eurostat. Extra-EU trade by partner. Retrieved from https://ec.europa.eu/eurostat/databrowser/view/ext_lt_maineu/default/table?lang=en. [in English].

6. COMMUNICATION FROM THE COMMISSION TO THE EUROPEAN PARLIAMENT, THE COUNCIL AND THE EUROPEAN ECONOMIC AND SOCIAL COMMITTEE. (2014). Trade, growth and intellectual property - Strategy for the protection and enforcement of intellectual property rights in third countries. /* COM/2014/0389 final */. Retrieved from https://eur-lex.europa.eu/legal-content/EN/TXT/?uri=CELEX:52014DC0389. [in English].

7. Report on the protection and enforcement of intellectual property rights in third countries. European Commission. Brussels, 27.4.2021 SWD(2021) 97 final. Retrieved from https://trade.ec.europa.eu/doclib/docs/2021/april/tradoc_159553.pdf. [in English].

8. Trade Profiles 2020. World Trade Organization. 404 p. Retrieved from www.wto.org/statistics. [in English].

9. Euro area international trade in goods surplus $€ 29.2$ bn $€ 30.1$ bn surplus for EU. Eurostat. newsrelease22/2021. 15 February 2021. [in English].

10. Eurostat. Intra-EU27 (from 2020) trade, by Member State, total product [TET00011]. Trade balance in million ECU/EURO. [in English]. 